\title{
Perkembangan Kognitif Anak Usia Dini (STPPA Tidak Tercapai) di TK Aisyiah Bustanul Athfal 2 Padangsidimpuan
}

\author{
Nur Imam Mahdi ${ }^{1}$ Fitri Ramadhini ${ }^{2}$ \\ e-mail: Imam@iain-padangsidimpuan.ac.id \\ f.ramadhini@gmail.com
}

\begin{abstract}
This research is motivated by the low development of cognitive abilities of chidren. This is because teachers still use conventional methods in learning plus family environmental factors that do not support. The purpose of this study is to determine the achievement of cognitive development of Sadewa in Class B TK Aisyiah Bustanul Athfal 2 Padangsidimpuan. In this study the subject of the study is a boy aged 5 years 7 months. This research is a qualitative research. The data that the author obtained include interviews with class teachers and parents Sadewa. From the results of the study authors conclude that Sadewa showed extreme cognitive left or low cognitive development.
\end{abstract}

Kata Kunci :Development Cognitive; Early Childhood.

\begin{abstract}
Abstrak
Penelitian ini dilatarbelakangi oleh rendahnya perkembangan kemampuan kognitif anak. Hal ini disebabkan guru masih menggunakan metode konvensional dalam pembelajaran ditambah faktor lingkungan keluarga yang tidak mendukung. Tujuan penelitian ini adalah untuk mengetahui ketercapaian perkembangan kognitif Sadewa di Kelas B TK Aisyiah Bustanul Athfal 2 Padangsidimpuan. Pada penelitian ini yang menjadi subjek penelitian adalah anak laki- laki berusia 5 tahun 7 bulan. Penelitian ini adalah penelitian kualitatif. Adapun data yang penulis peroleh meliputi wawancara dengan guru kelas dan orang tua Sadewa. Dari hasil penelitian penulis simpulkan bahwa Sadewa menunjukan kognitif ekstrim kiri atau perkembangan kognitif rendah.
\end{abstract}

Kata Kunci : Perkembangan Kognitif, Anak Usia Dini

\section{PENDAHULUAN}

Pendidikan Anak Usia Dini adalah bentuk penyelenggaraan pendidikan yang menitik beratkan pada peletakkan dasar kearah pertumbuhan dan perkembangan fisik (koordinasi motorik halus dan kasar), kecerdasan (daya pikir/kognitif, daya cipta, emosi, spiritual), sosial emosional, bahasa dan komunikasi sesuai dengan keunikan dan tahapan perkembangan yang

\footnotetext{
${ }^{1}$ Dosen Institut Agama Islam Negeri Padangsidimpuan

${ }^{2}$ Dosen Institut Agama Islam Negeri Padangsidimpuan
} 
dilalui oleh anak usia dini. Sedangkan anak usia dini adalah sosok individu yang sedang menjalani suatu proses perkembangan dengan pesat dan fundamental bagi kehidupan selanjutnya. Anak usia dini berada pada rentang usia 0-8 tahun. ${ }^{3}$

Pada masa Golden Years (0-8 tahun) merupakan masa keemasan, yang mana pada masa itu stimulus seluruh aspek perkembangan berperan penting untuk tugas perkembangan selanjutnya. Oleh karena itu masa awal kehidupan anak merupakan masa terpenting dalam rentang kehidupan seorang anak. Beberapa konsep yang disandingkan untuk masa anak usia dini adalah masa eksplorasi, masa identifikasi/imitasi, masa peka, masa bermain dan masa trost alter 1 (masa membangkang tahap 1$){ }^{4}$

Pada masa ini pertumbuhan otak sedang mengalami perkembangan yang sangat pesat. Berdasarkan penelitian tentang otak, tingkat kapabilitas kecerdasan anak sampai 4 tahun telah mencapai $50 \%$, pada usia 8 tahun mencapai $80 \%$ dan sisanya sekitar $20 \%$ pada saat berusia 8 tahun keatas.

Taman kanak-kanak merupakan salah satu bentuk pendidikan anak usia dini yang bertujuan untuk membantu meletakkan dasar-dasar ke arah perkembangan sikap, pengetahuan, keterampilan dan daya cipta yang diperlukan anak didik dalam menyesuaikan diri dengan lingkungan dan untuk pertumbuhan dan perkembangan selanjutnya. ${ }^{5}$ Sebagaimana dikemukakan oleh Havighurst, yang menyatakan bahwa perkembangan pada satu tahap perkembangan akan menentukan bagi perkembangan selanjutnya. Keberhasilan dalam menjalankan tugas perkembangan pada suatu masa akan menentukan keberhasilannya pada masa perkembangan berikutnya. ${ }^{6}$

Sebagaimana yang kita ketahui bersama secara praktis kognitif sangat familier sebagai barometer penilaian pada anak di Taman Kanak- kanak, jika seorang pendidik akan melakukan evaluasi tentu kognitif ditempatkan yang teratas, ini menunjukan pentingnya

\footnotetext{
${ }^{3}$ Haryanti, Upaya Meningkatkan Kemampuan Kosa Kata Anak Usia Dini Melalui Media Foto Skripsi, Prodi PGRA Sekolah Tinggi Pendidikan Islam (STPI) BIM Yogyakarta, Hlm.15-16.

${ }^{4}$ Hariyanto, Pendidikan Multikultural: Memahami Aspek Pola Perkembangan Nalar Pikir dan Perilaku Anak usia Dini. (Quantum, Jurnal Penelitian PAUD, Volume 1, Nomor 1, Juni 2012: 47-74. Yogyakarta: Fakultas Ilmu Tarbiyah dan Keguruan Uin Sunan Kalijaga),Hlm.58.

${ }^{5}$ Slamet Suyanto, Dasar-dasar Pendidikan Anak Usia Dini. (Yogyakarta: Hikayat Publising, 2005), hlm. 6.

${ }^{6}$ Mukhtar Latif, dkk. Orientasi Baru Pendidikan Anak Usia Dini; Teori dan Aplikasi. (Jakarta: Kencana Prenada Media Group, 2014), Hlm.22
} 
kognitif dalam kecerdasan anak. Jika anak akan menggambar, menghafal, dan membilang ini kaitanya dengan kognitif.

$\mathrm{Nah}$, atas dasar pentingnya kognitif penulis melakukan penelitian ringan atau mengamati sejauh mana perkembangan kognitif anak dari pra pengajaran dan sampai pada menggenyam pendidikan di PAUD. Dengan demikian perkembangan kognitif anak akan terdeteksi. Sehingga mengetahui seberapa jauh perkembangan kognitif anak.

Penelitian ini fokus pada perkembangan kognitif anak yaitu mengamati salah satu siswa saja yaitu Sadewa. Setting penelitian di kelas B TK Aisyiah Bustanul Athfal 2 Padangsidimpuan, Sadewa merupakan anak yang sangat Minder dan wali kelasnya juga mengatakan bahwa perkembangan kognitif Sadewa sangat rendah diantara temantemannya. $^{7}$

Penulis ingin memberikan tawaran pada sekolah memberikan refleksi atau langkahlangkah tepat untuk memperbaharui atau memperbaiki metode atau cara- cara yang akan diberikan selanjutnya. Penulis hanya akan mengemukakan mengenai perkembangan kognitif anak yan merupakan bagian dari aspek perkembangan anak usia dini.

\section{PEMBAHASAN}

\section{A. PENGERTIAN PERKEMBANGAN KOGNITIF ANAK USIA DINI}

\section{Pengertian Perkembangan Kognitif Anak Usia Dini}

Para psikolog berpendapat bahwa manusia mengalami perkembangan secara bertahap, mulai dari bayi, anak-anak, remaja, dewasa dan seterusnya. Walaupun klasifikasi tahapan-tahapan perkembangan berbeda antara psikolog yang satu dengan psikolog yang lain, tetapi yang jelas para psikolog itu menyadari adanya tahap perkembangan secara khusus pada anak usia dini.

Adapun pengertian perkembangan adalah bertambahnya struktur, fungsi dan kemampuan anak yang lebih kompleks, meliputi kemampuan sensori, gerakan, berkomunikasi dan berinteraksi, kognitif, bersosialisasi, kreativitas dan moral spritual.

Hurlock adalah salah satu pakar psikologi perkembangan anak paling terkemuka abad ini. Ia mengemukakan prinsip-prinsip perkembangan anak sebagai berikut: ${ }^{8}$

\footnotetext{
7 Hasil wawancara dengan Buk Dewi selaku Wali Kelas Sadewa Di TK (Jln. Yos Sudarso No. 58 Padangsidimpuan.) pada tanggal, 9 Maret 2020. Pukul 08.00-10.30 WIB

${ }^{8}$ Suyadi, dkk. Konsep Dasar PAUD. (Bandung: PT Remaja Rosdakarya, 2015),Hlm.48-50
} 
a. Perkembangan awal lebih pentin atau lebih kritis daripada perkembangan selanjutnya karena perkembangan awal menjadi dasar bagi perkembangan berikutnya. Apabila perkembangan awal membahayakan penyesuaian pribadi dan sosial anak, perkembangan sosial anak selanjutnya akan terganggu. Namun demikian, perkembangan awal (jika mampu mengetahuinya) dapat diubah atau disesuaikan sebelum menjadi pola kebiasaan.

b. Pola perkembangan dapat diprediksikan, walaupun pola yang dapat diprediksikan tersebut dapat diperlambat atau dipercepat oleh kondisi lingkungan di masa pra-lahir dan pasca-lahir.

c. Pola perkembangan mempunyai karakteristik tertentu yang dapat diprediksikan. Pola perkembangan yang terpenting diantaranya adalah adanya persamaan bentuk perkembangan bagi semua anak; perkembangan berlangsung dari tanggapan umum ke tanggapan spesifik; perkembangan terjadi secara berkesinambungan berbagai bidang berkembang dengan kecepatan yang berbeda dan terdapat korelasi dalam perkembangan yang berlangsung.

d. Setiap perkembangan pasti melalui fase-fase tertentu secara periodik mulai dari periode pra-lahir (masa pembuahan sampai lahir), periode neonatus (lahir sampai 1024 hari), periode bayi (2 minggu sampai 1 tahun), periode kanak-kanak awal (2 sampai 6 tahun), periode kanak-kanak akhir (6 sampai 13-14 tahun), dan periode puber (16 sampai 18 tahun). Dalam semua periode tersebut terdapat saat-saat keseimbangan dan ketidakseimbangan; serta pola perilaku yang normal dan yang terbawa dari periode sebelumnya, biasanya disebut perilaku "bermasalah" (abnormal).

e. Setiap bidang perkembangan pasti ada harapan sosial untuk anak. Harapan sosial tersebut adalah tugas perkembangan yang memungkinkan para orang tua dan guru TK mengetahui pada usia berapa anak mampu menguasai berbagai pola perilaku yang diperlukan bagi penyesuaian sosial yang baik.

Menurut Hurlock, prinsip yang dikemukakan di atas belum final. Oleh karena itu, jika penelitian tentang perkembangan pada anak dilanjutkan dari masa ke masa, tidak menutup kemungkinan akan ditemukannya prinsip-prinsip perkembangan yang lain. 
Kognitif merupakan proses berfikir, yaitu kemampuan individu untuk menghubungkan suatu kejadian atau peristiwa. Hal ini sesuai dengan pendapat Gagne (dalam Darsinah: 2011) bahwa kognitif adalah proses yang terjadi secara internal di dalam susunan syaraf pada waktu manusia sedang berfikir. Kemampuan kognitif ini sejalan dengan perkembangan fisik dan syaraf-syaraf yang berada di pusat susunan syaraf terkait. ${ }^{9}$

Abdullah Nashih Ulwan memberikan panduan yang lengkap bagi terwujudnya pola asuh yang sempurna/lengkap karena selain memuat berbagai macam dalil naqli mangacu langsung kepada nash-nash Al-Qur'an dan Hadits yang shohih, beliau melengkapinya pula dengan bukti-bukti ilmiah dan rasional. membagi dalam tiga bagian yang setiap bagian memuat beberapa pasal dan setiap pasalnya mengandung beberapa topik bahasan. Adapun dalam konteks kognitif masuk pada kajian bagian dua (2) pasal empat (4) tentang pendidikan rasio/ akal, maka akal adalah sejalan dengan kognitif. ${ }^{10}$

Perkembangan Kognitif adalah perkembangan pikiran. Pikiran adalah bagian dari berpikir dari otak. Bagian yang digunakan yaitu untuk pemahaman, penalaran, pengetahuan, dan pengertian. Perkembangan pikirannya, seperti: (1) belajar tentang orang, (2) belajar tentang sesuatu, (3) belajar tentang kemampun-kemampuan baru, (4) memperoleh banyak ingatan, dan (5) menambah banyak pengalaman sepanjang perkembangan pikiran anak, maka akan lebih cerdas.

\section{Teori Dasar Perkembangan Kognitif}

Pada rentang usia 3-4 sampai 5-6 tahun, anak mulai memasuki masa pra sekolah yang merupakan masa kesiapan untuk memasuki pendidikan formal yang sebenarnya di sekolah dasar. Menurut Montessori, masa ini ditandai dengan masa peka terhadap segala stimulasi yang diterimanya melalui pancaindra. Masa peka memiliki arti penting bagi perkembangan setiap anak. Hal ini berarti bahwa apabila orang tua mengetahui anaknya telah memasuki masa peka dan mereka segera memberi stimulasi yang tepat, maka akan mempercepat penguasaan terhadap tugas-tugas perkembangan pada usianya.

${ }^{9}$ Kuswana Sunaryo Wowo.,Taksonomi Kognitif,( Bandung : PT Remaja Rosdakarya.,2012).hlm 77.

${ }^{10}$ Abdullah Nasih ulwan, Tarbiyat Al-Aulad Fi al- Islam, Diterjemahkan oleh : Drs. Jamaluddin Miri dengan Judul Pendidikan Anak Dalam Islam, (Jakarta : Pustaka Amani, 2002), Hlm. 167. 
Piaget berpendapat bahwa, anak pada rentang usia ini masuk dalam perkembangan berpikir pra-operasional konkret. Pada saat ini sifat egosentris pada anak semakin nyata. Anak mulai memiliki perspektif yang berbeda dengan orang lain yang berbeda di sekitarnya. Orang tua sering menganggap periode ini sebagai masa sulit karena anak menjadi susah diatur, bisa disebut nakal atau bandel, suka membantah dan banyak bertanya. ${ }^{11}$

\section{Faktor yang mempengaruhi kemampuan kognitif}

Sujiono (dalam Darsinah, 2011 : 14) mengemukakan bahwa faktor yang mempengaruhi perkembangan kognitif anak meliputi: (1) Faktor hereditas/keturunan, (2) Lingkungan, (3) Kematangan, (4) Pembentukan, (5) Minat dan bakat, (6) Kebebasan. Sedangkan menurut Kartini Kartono (dalam Darsinah, 2013:12) Perkembangan kognitif dipengaruhi oleh hereditas/keturunan, lingkungan, kematangan dan aktifitas. ${ }^{12}$

\section{B. INDIKATOR TAHAP PENCAPAIAN PERKEMBANGAN KOGNITIF (STPPA)} AUD

Bickerson, Perkins dan Smith (dalam Darsinah, 2013:3) mengidentifikasikan kemampuan kognitif manusia sebagai berikut: (1) Kemampuan mengklasifikasikan pola-pola objek, (2) Kemampuan menalar secara deduktif (3) Kemampuan menalar secara induktif (4) Kemampuan mengembangkan dan menggunakan konsep, dan (5) Kemampuan memahami. Menurut PLPG PAUD, 2013:378. Kognitif mencakup berbagai aspek mental seperti: memperhatikan, menggingat, melambangkan, mengelompokkan, merencanakan, menalar, memecahkan masalah, menghasilkan dan membayangkan.

Adapun indikator tingkat pencapaian perkembangan kognitif pendidikan anak usia dini dijelaskan dalam tabel berikut: ${ }^{13}$

${ }^{11}$ Ahmad Susanto, Perkembangan Anak usia Dini; Pengantar dalam Berbagai Aspeknya. (Jakarta: Kencana Prenada Media Group, 2012), Hlm.49

${ }^{12}$ Bagus Mahardika, Upaya Peningkatan Kognitif Anak Melalui Bermain Istana Pasir Skripsi, Prodi PGRA Sekolah Tinggi Pendidikan Islam (STPI) BIM Yogyakarta, Hlm.11.

13 Suyadi, dkk. Implementasi dan Inovasi Kurikulum PAUD 2013; Program Pembelajaran Berbasis Multiple Intelligences. (Bandung: PT Remaja Rosdakarya, 2015), Hlm.36-37 


\begin{tabular}{|c|c|c|}
\hline $\begin{array}{l}\text { Lingkup Perkembangan } \\
\text { Kognitif }\end{array}$ & Usia $4-<5$ tahun & Usia 5 - $\leq 6$ tahun \\
\hline $\begin{array}{l}\text { A. Pengetahuan umum } \\
\text { dan sains. }\end{array}$ & $\begin{array}{l}\text { 1. Mengenal benda berdasarkan } \\
\text { fungsi untuk } \\
\text { memotong, pensil untuk } \\
\text { menulis). } \\
\text { 2. Menggunakan benda-benda } \\
\text { sebagai permainan simbolik } \\
\text { (kusrsi sebagai mobil). } \\
\text { 3. Mengenal gejala sebab-akibat } \\
\text { yang terkait dengan dirinya. } \\
\text { 4. Mengenal konsep sederhana } \\
\text { dalam kehidupan sehari-hari } \\
\text { (gerimis, hujan, gelap, } \\
\text { terang). } \\
\text { 5. Mengekspresikan sesuatu } \\
\text { sesuai dengan idenya sendiri. }\end{array}$ & 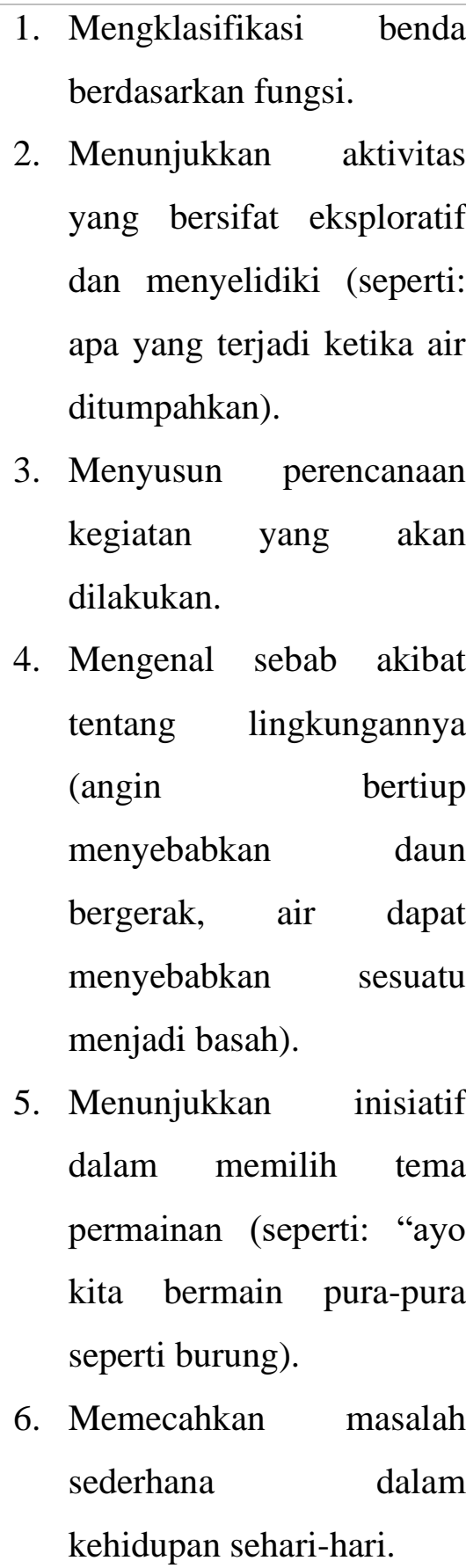 \\
\hline $\begin{array}{l}\text { B. Konsep bentuk, } \\
\text { warna, ukuran, dan } \\
\text { pola. }\end{array}$ & $\begin{array}{l}\text { 1. Mengklasifikasikan benda } \\
\text { berdasarkan bentuk atau } \\
\text { warna atau ukuran. } \\
\text { 2. Mengklasifikasikan benda ke }\end{array}$ & $\begin{array}{l}\text { 1. Mengenal perbedaan } \\
\text { berdasarkan ukuran "lebih } \\
\text { dari", "kurang dari", dan } \\
\text { "paling/ter". }\end{array}$ \\
\hline
\end{tabular}




\begin{tabular}{|c|c|c|}
\hline & $\begin{array}{l}\text { dalam kelompok yang sama } \\
\text { atau sejenis atau kelompok } \\
\text { yang berpasangan dengan } 2 \\
\text { variasi. } \\
\text { 3. Mengenal pola AB-AB dan } \\
\text { ABC-ABC. } \\
\text { 4. Mengurutkan benda } \\
\text { berdasarkan } 5 \text { seri ukuran dan } \\
\text { warna. }\end{array}$ & $\begin{array}{l}\text { 2. Mengkalsifikasikan benda } \\
\text { berdasarkan warna, } \\
\text { bentuk, dan ukuran } 3 \\
\text { variasi). } \\
\text { 3. Mengklasifikasikan benda } \\
\text { yang lebih banyak ke } \\
\text { dalam kelompok yang } \\
\text { sama atau sejenis, atau } \\
\text { kelompok berpasangan } \\
\text { yang lebih dari } 2 \text { variasi. } \\
\text { Mengenal pola ABCD- } \\
\text { ABCD. } \\
\text { Mengurutkan } \\
\text { berdasarkan ukuran dari } \\
\text { paling kecil ke paling } \\
\text { besar atau sebaliknya. }\end{array}$ \\
\hline $\begin{array}{l}\text { C. Konsep bilangan, } \\
\text { lambang bilangan } \\
\text { huruf }\end{array}$ & $\begin{array}{l}\text { 1. Mengetahui konsep banyak } \\
\text { dan sedikit. } \\
\text { 2. Membilang banyak benda } \\
\text { satu sampai sepuluh. } \\
\text { 3. Mengenal konsep bilangan. } \\
\text { 4. Mengenal lambang bilangan. } \\
\text { 5. Mengenal lambang huruf. }\end{array}$ & $\begin{array}{l}\text { 1. Menyebutkan lambang } \\
\text { bilangan 1-10. } \\
\text { 2. Mencocokan bilangan. } \\
\text { 3. Mengenal berbagai macam } \\
\text { lambang huruf vokal dan } \\
\text { konsonan. }\end{array}$ \\
\hline
\end{tabular}

\section{F. DESKPRIPSI PERKEMBANGAN SUBJEK}

Adapun profil anak sebagai berikut :

Nama Anak

Tempat Tanggal Lahir

Usia saat ini

Jenis Kelamin

Ibu
: Sadewa

: Padangsidimpuan, 09 Januari 2015

: 5 Tahun

: Laki- laki

: Rina 
Ayah

Alamat

Sekolah

Kelas
: Fery Zulkarnain

: Jln. Yos Sudarso, No.58 Padangsidimpuan.

: TK Aisyiah Bustanul Athfal 2 Padangsidimpuan

: TK B

Sadewa lahir di Rumah Sakit Inanta, dengan alami tanpa caesar, ketika ibunya berusia 36 tahun, sadewa adalah anak ke 3 dari 4 bersaudara, jarak usia yang jauh dari 2 kakaknya sekitar 9 dan 7 tahun. Kondisi ketika lahir, berat badan 3,3 Kg dan panjang badan $46 \mathrm{~cm}$. Ukuran tubuh yang sehat untuk anak bayi yang baru lahir.

Sejarah perkembangan subjek, berawal dari lahir, Ketika ibu Rina mengandung Sadewa, ibu Rina masih mengajar di SD hingga sampai 6 bulan. pada kondisi kandungan perut sudah besar ia masih berpergian. Padahal menurut kata dokter di rentang 5 bulan sampai menjelang kelahiran, seorang ibu menggandung di anjurkan untuk banyak istirahat tidak bekerja keras, dan bergerak berlebihan. Tapi ini benar-benar dialami oleh sang ibu, mungkin ini yang memicu juga psikis sadewa terkait kognitifnya yang rendah.

Bayi dalam perut ibu dengan kondisi ibu yang selalu bergerak berlebihan bayi yang masih dalam kandungan merasa tidak bisa menyalurkan kecerdasan kognisi. Jika dalam perut ibu bayi tertekan atau stress tentu bayi akan merasakan hal yang sama, dan bayi juga tidak bisa mernstimulasi kognitif seperti bergerak-gerak dalam perut ibu, menendang, dan berputar dalam perut. Pasalnya anak tentu tidak akan mengalami aktifitas seperti ini jika kondisi ibu terlalu tertekan atau stress dalam menjalani pekerjannya. Aktifitas tersebut padahal merangsang kognitif anak, memang porsi kogniti bayi seperti ini masih belum kompleks, tapi semacam ini merupakan dasar. Jika dasarnya tidak berjalan sesuai tahapannya, tentu kognitif selanjutnya tak berarti apa-apa, atau hidup dalam kognitif yang pincang karena kognitif dasarnya tadi sudah rapuh.

Ibu sebagai teman pertama anak juga tidak didapati oleh sadewa. Pasalnya setelah lahiran menjelang masuk TK Sadewa sering di tinggal Orang tua, karena memang kondisi ibu sebagai guru SD dan Bapak sebagai pekerja di kantor. Oleh karena itu wajar mas sadewa sering memberontak dalam analisa penulis sadewa kurang kasih sayang atau perhatian dari ayah dan ibu. 
Tahap perkembangan kognitif mas sadewa berusia 1 tahun secara umum masih sama dengan perkembangan kognitif teman yang lainnya, dia mampu membedakan mana ibu mana ayah, jika ia haus ia menangis mencari sang ibu ini menandakan kognitif jalan bisa membedakan mana ibu mana ayah, kata sang ibu ketika masih berusia 1 tahun ia juga dapat mencegah dari penculikan, katanya ketika masih kecil ia tidak mau diajak saudaranya, alasannya saat itu saudaranya belum pernah datang kerumah sebelumnya. Ia datang saat berkumpul keluarga waktu hari raya idul fitri saja lantas ia tidak mau diajak, sepertinya dia sudah bisa mengetahui mana orang asing mana temannya. "Jadi menurut saya sadewa itu sudah dapat mencegah penculikan loh pak imam, ucap bu rina ".

Selanjutnya perkembangan kognitif pada usia 2 tahun sadewa sudah bisa berbicara, apa yang dikatakan ibu dan ayah ia sudah dapat ditirukan, namun anak ini sedikit telat berbicara tapi dia lebih cepat lancar berjalan disbanding dengan berbicara. Pada usia tiga tahun ia mulai permainan rekontruksi atau menata balok, karena pada usia 3 tahun ia sudah masuk sekolah di kelompok bermain KB, saat di KB ibunya juga menceritakan apa saja yang disukai Sadewa, seperti bermain balok, bermain plastisin, bermain bola, bermain pasir dll.

Memang ketika sudah bermain pasir ibunya kewalahan, setiap ibunya menjemput pulang sekolah sadewa selalu di area bermain pasir anehnya ketika diajak untuk pulang sadewa selalu menolak padahal waktunya belajar dikelas seperti menggambar, menulis, mewarnai, dan tanya jawab dia selalu males-malesan bahkan sering tidak memperhatikan gurunya, ia lebih memilih asyik-asyikan bermain sendiri.

Penulis juga penasaran pada saat itu, jadi setiap ibunya menjemput untuk pulang sadewa selalu menolak, dia merasa asyik dengan dirinya saat bermain pasir, penulis dalam hati juga bertanya- tanya apakah dia tidak suka dengan ibunya atau dia suka dirumah, atau dia lebih menyukai dunia natural seperti bermain pasir, tapi setelah penulis lacak memang anak ini condong ke dunia natural, tapi setelah penulis mencoba bertanya pada mas sadewa, kenapa dijemput pulang ibu menolak?? alasannya. "Dirumah aku bosan, aku tidak punya teman dan dirumah aku Cuma dengan simbahku saja pak dan dirumah ibu selalu sibuk, nanti setelah aku di jemput ibu aku itu ditinggal pergi lagi sama ibu, dan bapak juga tidak ada dirumah bapakku itu pulangnya malam".

Penulis dalam penelitian di TK selama 2 hari tapi dalam 2 hari penelitian penulis menjumpai masalah yang sama yaitu mas sadewa selalu menolak pulang ketika di jemput, 
Padahal teman- teman sudah tidak ada yang bermain pasir. Tapi dia bermain sendiri. iyaa,, walau akhirnya juga mau si karena dikasih bujukan entah dibelikan, jajan, mainan, atau di belikan sosis

Dalam eksperimennya bermain pasir ia membat gundukan seperti gunung, terus ditambahkan aliran sungai, seperti yang dikatakan ibunya ia suka berimajinasi membuat gundukan yang menyerupai gunung ini juga menandakan kognitifnya jalan, namun pada usia dua 5 tahun ketika ia memasuki TK B yang pemahaman kognitif sudah begitu kompleks ia sangat rendah ketinggalan dengan perkembangan kognitif teman- teman yang lain.

Dalam pembelajarannya ketika penulis mengamati kognitif mas sadewa ini terlihat sekali kognitif sangat rendah dibanding teman-teman lainnya. Hafalan misalnya, pada waktu itu Buk Dewi mengajarkan kosa kata bahasa inggris, guru atau pendidik mengenalkan 5 kosakata berurutan (mata, hidung telingga, rambut, kaki) disertai bahasa inggrisnya, lalu guru bertanya kepada peserta didik, guru menyebutkan bahasa Indonesia dan peserta didik menyebutkan bahasa inggrisnya. Kebanyakan teman-temannya dapat menjawabnya dengan benar, tapi ketika sadewa ditanya ia selalu menjawab ngawur atau salah-salahan.

Berulang kali guru bertanya pasti salah. Guru merasa penasaran dengan sadewa akhirnya ia driil suruh menghafal. Ketika ia menghafal dengan dipancing pancing akhirnya dia bisa menghafal ke 5 kosakata beserta bahasa inggrisnya. Karena guru sudah mengetahui ia bisa menghapal secara berurutan akhinya guru mencoba bertanya lagi secara acak, seperti biasa guru bertanya menyebutkan bahasa Indonesia, rambut bahasa ingrisnya apa? lalu sadewa menjawab hair, jawaban benar. guru bertanya lagi kaki bahasa inggrisnya apa?, anak mulai binggung ia melihat ke atas mencoba menggali hafalan yang ada di memorinya, lalu sadewa menjawab fo apa gitu bu saya lupa. Akhirnya guru memberi jawaban yang benar, foot sadewa yang benar, dan guru masih punya pertanyaan 3 lagi.

Pertanyaan yang ketiga sampai ke 5 anak tidak berkata apa apa. Artinya jawaban sadewa dari 5 pertanyan benar 1soal, dan 1 soal lagi setengah ingat ia Cuma menjawab fo dari foot, dan 3 soal pertanyaan dia tidak bisa menjawab sama sekali, untuk itu penulis menarik kesimpulan bahwa pada pembelajaran kosakata taraf kognitif ia masih rendah, sadewa dapat menghafal karena data berurutan, tapi ketika ditanya pendidik secara acak dia belum mampu menjawab 5 soal benar, mencapai standarnya kognitif saja belum buktinya dengan mencari 3 soal benar dia belum mampu. 
Berkaitan dengan kemampuan kognitif membilang angka penulis melihat bahwa sadewa ini termasuk lola mikir atau lodingnya lama, nilai penjumlahan untuk dibawah 20 saja ia sampai menggunakan semua jari kaki dan jari tangan, padahal di TK B sebenarnya sudah mampu mengawang, teman- teman lain penulis lihat sudah top cer dalam berhitung istilahnya sudah diluar kepala karena memang angka 20 tidak terlalu sulit untuk porsi TK B.

Selanjutnya dalam pemahaman kode atau menggunakan symbol symbol tersurat, isyarat,sadewa ini menurut penulis dalam pemahaman tersebut dia sangat rendah. Misalnya ketika jam pulang, di TK sendiri setelah jam belajar selesai juga ada kegiatan makan siang, ketika guru menyediakan buah-buahan (semangka)disitu anak bebas mengambil berapapun, karena memang sudah dipotong-potong segitu banyak, namun wajarnya anak itu mengambil 2 atau 1 potong saja sudah cukup.

Pada saat itu dia makan terakhir dan sisa semangka masih ada 8 potong. Ketika dia sudah menggambil 2 mau menggambil lagi lalu dikomentari pak mansyur dengan bahasa isyarat. Sudanh makan berapa potong semangka sadewa?? Lalu anak menjawab" 2 potong pak”. Berarti sudah kenyang harusnya. Ehh, malah anak menggambil 2 potong lagi. Alasannya belum kenyang. Padahal pesan pak mansyur yang dikandung maksud adalah anak di suruh berhenti makan. Karena dia tidak memahami ilmu retorika jadi acuh tak acuh tetap makan karena tidak ada larangan secara jelas untuk berhenti. Oleh karenanya penulis memandang kognisi penalaran sadewa masih rendah belum mamahami isyarat yang diberikan pak mansyur.

Adapun dari beberapa kumpulan lembar kerja LK banyak ditemukan nilai- nilai yang di peroleh rendah jauh dibawah rata rata, misalnya ketika anak disuruh mewarnai jalan atau rute, yang mana maksud pembelajaranya adalah mencari jalan tercepat sampai lokasi tujuan, ia belum memilih rute yang memang benar-benar rute tercepat, sadewa memilih rute ke dua yang menunjukan rute bukan tercepat padahal perintahnya mencari rute tercepat.

Dalam bahasa penulis kecerdasan kognitif ada dua yaitu ekstrim kanan dan ekstrim kiri. Ekstrims kanan tertuju bagi yang kognitif diatas rata-rata, dan sedangkan ekstrim kiri tertuju pada kognitif dibawah rata-rata. Pada hasil observasi penulis sadewa benar-benar masuk dalam kategori kognitif ekstrim kiri. 


\section{G. ANALISIS PREDIKSI DAN MODIFIKASI}

Melihat perkembangan konitif anak terindikasi ekstrim kiri, tentu pendidik dan orang tua benar-benar bersinergi untuk mengatasi masalah yang menimpa pada mas sadewa. Hal tersebut merupakan tanggung jawab pendidik dan orang tua. Menurut penulis tidak ada orang yang bodoh yang ada hanya seorang anak belum menemukan guru yang cocok. Jika dirunut masalah dari kedua orang tua itu memang sumber masalahnya. Sebenarnya anak butuh kasih sayang dari orang tua, memang waktu sangat sulit dipertemukan antara anak dan keluarga karena masing- masing mempunyai kegiatan sendiri- sendiri.

Terpenting menurut penulis adalah sempatkan waktu untuk bercengkrama dengan anak, menanyakan kegiatan anak disekolah, berdiskusi, yang terpenting waktu sedikit yang orang tua miliki itu bermakna dalam pertemuannya. Berikan kasih sayang yang mendalam kasih reward jika anak mendapatkan sesuatu yang ia peroleh dengan usahanya. Sedangkan jika masalahnya pada metode guru yang konvensional dalam mengajar diusahakan lebih kreatif untuk dapat mewujudkan minat bakat yang ada pada anak.

Berikan pengajaran yang mudah diterima anak. Lihat karakter anak jangan dipukul rata dalam mengajarkan pada setiap anak. Karena pada hakikatnya anak berbeda, beda kepala beda pula pemikiran. Oleh karenanya ikuti pemikiran anak dan kesukaan anak. Lalu ajarkan pembelajaran yang humanis yang menentramkan jiwa anak, tidak selalu menuntut anak dengan kemauan gurunya. Dengan demikian akan menjadi anak yang hebat di masa mendatang.

\section{H. KESIMPULAN}

Perkembangan Kognitif adalah perkembangan pikiran. Bagian yang digunakan yaitu untuk pemahaman, penalaran, pengetahuan, dan pengertian. Dalam bahasa penulis kecerdasan kognitif ada dua macam yaitu ekstrim kanan dan ekstrim kiri. Ekstrims kanan tertuju bagi yang kognitif diatas rata-rata, dan sedangkan ekstrim kiri tertuju pada kognitif dibawah rata-rata. Sedangkan Sadewa menurut ciri-ciri yang ada masuk dalam kategori kognitif rendah.

Mengatasi anak perkembangan kognitif rendah adalah dengan cara orang tua sempatkan waktu untuk bercengkrama dengan anak walau sesibuk apapun orang tua. menanyakan kegiatan anak disekolah, berdiskusi, dan memberikan pengajaran yang mudah diterima anak. 


\section{DAFTAR PUSTAKA}

Haryanti, 2013. Upaya Meningkatkan Kemampuan Kosa Kata Anak Usia Dini Melalui Media Foto Skripsi, Prodi PGRA Sekolah Tinggi Pendidikan Islam (STPI) BIM Yogyakarta

Hariyanto, 2012.Pendidikan Multikultural: Memahami Aspek Pola Perkembangan Nalar Pikir dan Perilaku Anak usia Dini. Quantum, Jurnal Penelitian PAUD, Volume 1, Nomor 1, Juni 2012: 47-74. Yogyakarta: Fakultas Ilmu Tarbiyah dan Keguruan Uin Sunan Kalijaga.

Hasil wawancara dengan Ibu Dewi selaku Wali Kelas Sadewa Di TK B(Jln.Yos Sudarso No. 58 Padangsidimpuan.) pada tanggal, 9 Maret 2020. Pukul 08.00-10.30 WIB.

Kuswana Sunaryo.2012. Taksonomi Kognitif, Bandung : PT Remaja Rosdakarya

Latif Mukhtar. 2014. Orientasi Baru Pendidikan Anak Usia Dini; Teori dan Aplikasi. Jakarta: Kencana Prenada Media Group.

Mahardika, Bagus.2016. Upaya Peningkatan Kognitif Anak Melalui Bermain Istana Pasir Skripsi, Prodi PGRA Sekolah Tinggi Pendidikan Islam (STPI) BIM Yogyakarta.

Slamet Suyanto.2005. Dasar-dasar Pendidikan Anak Usia Dini. Yogyakarta: Hikayat Publising

Suyadi, 2010.Psikologi Belajar PAUD, Yogyakarta: Pedagogia

Susanto,Ahmad. 2012. Perkembangan Anak usia Dini; Pengantar dalam Berbagai Aspeknya. Jakarta: Kencana Prenada Media Group

Suyadi, dkk.2015. Implementasi dan Inovasi Kurikulum PAUD 2013; Program Pembelajaran Berbasis Multiple Intelligences. Bandung: PT Remaja Rosdakarya

Ulwan, Abdullah Nashih. 2002.Tarbiyat al-Aulad fi al-Islam, diterjemahkan oleh : Drs. Jamaluddin Miri, Lc dengan judul Pendidikan Anak dalam Islam, Jakarta, Pustaka Amani. 